\title{
An Investigation of Classroom Practices in Teaching Listening Comprehension at English Education Program
}

\author{
Nurhafni Siregar* \\ Sekolah Tinggi Keguruan dan Ilmu Pendidikan (STKIP), Tapanuli Selatan, Sumatera Utara, Indonesia
}

Corresponding Author: Nurhafni Siregar, E-mail: afniesiregar@gmail.com

\section{ARTICLE INFO}

\section{Article history}

Received: September 08, 2017

Accepted: November 02, 2017

Published: December 30, 2017

Volume: 8 Issue: 6

Advance access: December 2017

Conflicts of interest: None

Funding: None

\section{Key words:}

Classroom Practices,

Listening Comprehension

\begin{abstract}
The objective of this study is to investigate how the classroom practice in teaching listening comprehension at English Education Program of STKIP Tapanuli Selatan in 2016/2017 Academic Year is. The informants of this research were all of second semester students of STKIP Tapanuli Selatan in 2016/2017 academic year and a lecturer of listening comprehension at STKIP Tapanuli Selatan (63 students and one lecturer). A descriptive study was used to achieve the objective of the study. The sample was taken by cluster sampling. The data were collected by using interview to know how the lecturer carried out the teaching practice of listening, and questionnaire for the students and observation were used to find out how the calssroom activities were conducted. The descriptive analysis was used to anayse the data. Based on the data analysis, it was found that: (1) the lecturer carried out listening activities into four parts, they are preparation, prediction stage, listening, and post listening, and (2) the practice of teaching listening was effective related to the teaching pedagogical procedures in teaching listening comprehension. although there were some points that should be practice further. Based on the findings, it was recomended that the lecturer and the students may apply the less activities that had not been done.
\end{abstract}

\section{INTRODUCTION}

Listening comprehension is one of the basic skills that soluld be paid attention by the learners and teachers in carrying out the teaching and learning process in order to achieve better learning purpose especially in English. Listening is not just to listen, but the meaning of what we hear must be comprehended. Students with good listening comprehension skill will be able to participate more effectively in communicative situation. So, listening comprehension is a fundamental language skill in which students need to gain adequate proficiency. In listening, we need more attention and concentration to comprehend the sound or the listening material. At higher level of learning, the ability to listen effectively is very necessary for studentsin order that they understand different kinds of materials given by the lecturers.

To get the purpose, every techer or lecturer have to do effective teaching in classroom practice. Unfortunately, based on the pre survey that was conducted by the researcher, it was found out that the competence of second semester students of SKIP Tapanuli Selatan in 2016/2017 academic year especially in English Education Program is unsatisfactory (the persentage of the students who got the criteria of very good in listening comprehension course is only $12 \%$ ). Basically, a variety factors such as classroom activities, teaching materials, and evaluation may contribute to the successful of listening instruction. The traditional practice of teaching listening comprehension should be avoided. It means that the output oriented should be minimilized. On the other words, the effective teaching is based on the process oriented in order that the students are accustomed to apply learning autonomy in listening. Thus, how is the teaching practice in English languge edudaction program of STKIP tapanuli Selatan? In order to answer the question, it is important to investigate the classroom practice in teaching listening comprehension at English Education Program of STKIP Tapanuli Selatan in 2016/2017 Academic Year.

Based on the previous introduction, listening is an activities that involve receiving, deciphering, and perceiving messages with intent to respond. It is a process that enable the brain to construct a meaning from the sounds heard. Underwood (1989:1) states that listening is an activity to pay attention to what is heard. Similiarly, Richards (2008: 3) also says, "listening comprehension is the traditional way of thinking about the nature of listening. Indeed, in most methodology manuals listening and listening comprehension are synonymous. Nation and Newton (2009: 38) also say that listening is the way of learning the language by giving the information to the learners from which to build up the knowledge necessary for using the language. Therefore listening is the skill which required someone to listen well to somebody.

Based on the previous opinions, it can be concluded that listening comprehension is a process of thinking, understanding and remembering what the speaker said. In order to 
share the message with the speaker, the listener must actively contribute skills and knowledge from both linguistic and nonlinguistic resources. The listening comprehension consists of understanding the main ideas, the detail information, vocabulary, and implicit meaning.

The main idea is what the paragraph is about. It means that main idea is the main information of what speakers told (Beech, 2005: 5). Meanwhile, Markham (2006: 2) states that the main idea is the most important idea in a passage, or piece of writing. The main idea tells what the writing is mostly about. Thus, that main idea is the principal point of what the speaker said about the topic. It sums up the speaker's primary message.

Detail information is the supporting details which is the specific information that guide us to full understanding to the main idea. According to Beech (2005: 5), the details support or tell more about the main idea. Then, Markham (2006: 2) also says that details are pieces of information that tell about the main idea". It means that details are explain about the main idea.

Vocabulary is the words choice that are used to express our thingking and opinions. Neuman and Dwyer (2009: 385) define vocabulary as words that must be known to communicate effectively in speaking (expressive vocabulary) and words in listening (receptive vocabulary). This definition has a similiar concept to the opinion that vocabulary is the total number of words that are needed to communicate ideas and express the speakers' meaning. That is the reason why it is important to learn vocabulary (Alqahtani, 2015: 25). These two opinions indicate that vocabulary is all words that are used in communication especially in speaking.

Implicit meaning is the meaning of the expression that is not mention explicitely in the text. Not all of the meaning which is being communicated is stated overtly in the forms of the source language text. We should understand the text or the topic that speaker told so that we can catch the meaning implicitely. According to Larson in Al-Zughoul (2014: 168), "Implicit meaning is a meaning that is not shown but it is the part of the conversation or intention to convey the speaker". Futhermore, Al-Zughoul (2014: 168) says, “implicit meaning needs to be treated appropriately because it has the implied information which the reader may not know". So, it can be concluded that implicit meaning is a meaning that can not shown by the words. We should understand about the topic so that we can get the meaning clearly.

Related to the above factors, it is essential to understand about the practice itself in classroom activities. It means that classroon practice is the process of teaching and learning process where the teacher is involved in applying strategies and techniques to achieve the purpose of learning. It is important to pick topics that will be interesting for students. When a topic is interesting, it generates enjoyment that contributes to motivate the learner which is resulted with high concentration at the time of listening. However, there are some factors that must be considered by a lecturer in teaching listening comprehension, they are teaching methods, teaching materials, and evaluation.

Teaching method refers to the general principles, pedagogy and management strategies used for classroom instruction. In teaching method a lecturer needs intellectual, attitudes and approaches. Sanjaya (2009: 147) says that teaching method is a away that is used by the techer in implementing the planning that has been arranged in real activities in order that the optimal purpose of teaching and learning process can be achieved. Liu and Shi (2008: 5) also says that a teaching method is characterized by teachers to achieved the desired learning of the students. The two opinions indicate that the teaching method is an organization and application of teaching technique, teaching materials, and supplementary materials by the lecturers, which aims to achieve the teaching and learning objectives.

A teaching material is a means of learning which function is as a main component of teaching and learning. Teaching material also the resources a lecturer uses to deliver instruction. Chomsin \& Jasmadi (2008: 40) state that teaching materials contain the materials, methods, and all aspects that used in teaching learning process to achieve learning objectives. Moreover, according to Suwarni (2014: 98), the components of teaching material consist of curriculum, objectives, syllabus, kinds and function of teaching material, teacher and students' role in teaching learning process, and relevance of the learning. Thus, teaching material is important in teaching learning process so that a lecturer plays an important role in designing instructional materials to determine the success of process of teaching and learning.

Evaluation is the comparison of actual (project) impacts against the agreed strategic plans. It looks at the original objectives, at what was accomplished, and how it was accomplished. It can be formative that is taking place during the life of a project or organisation, with the intention of improving the strategy or way of functioning of the project or organisation. According to Bazo et al., (2007: 66), evaluation is a means of analyzing the effectiveness of the educational curriculum and for making effective change for further plan. While Sofyan (2013: 217) explained that evaluation is a process of planning, achieve, and provide information to make a decision. The persfectives indicates that evaluation is a procedure or method of knowing whether or not the teaching and learning process have been done by the tachers effectively and properly; whether the indicators, the materials, the learning strategies and media, the assessment procedures, and test items are in agreement with the competencies, the learners, and the learning situation.

Related to the above illustration, in order to achive the learning objectives of listening comprehension activities, the experts' concept of effective teaching listening comprehension is very essential to understand. Sheerin in (Debela, 2015:18) for example says that the effective teaching of listening consists of preparation, adequate support and appropriate tasks together with positive feedback, error analysis, and remedial action.

Preparation means that before applying the planning that has been proposed, a lecturer should prepare the syllabus and the lesson plan. To help the students to predict the specific information needed, the visual supports should be available such as graphs, maps, pictures, diagrams, and transcript. In addition, the positive feedback is given to the students in 
order that they are sure tomake succesful as often possible. Further, it is also important di diagnose the failure of the students due to the improvemant of their difficulties. However, the activities of listening involves pre-listening, while listening, and post listening are the part of activities that should be considered in listening instruction.

Pre-listening activity is to prepare the instruction in order to build the students' background knowledge, to make the contect explicit, to state the purposes and roles, procedures and learning goal (Rost, 1990:323). While listening activity involves a variety of tasks that the students do during the listening, such as prediction, comprehnding the message, revise prediction. This stage is used to help the students to develop their skill in understanding spoken language (Underwood, 1989:45). The last is post listening which is aimed at connecting the students' ideas and and what they have heard. The activities of post listening are to check whether the students have understood, to reflect why they failed to understand, to give opportunity to the students in considering the attitude and manner of the text, and expand and integrate the listening text to other languge skills such as speaking and writing (Underwood, 1989:74-75).

The above three activities indicates that in order to make the teaching of listening more effective, the lecturer or the teacher must make appropriate preparartion in planning and implementing the listening activities in the classroom. The classroom management is one of the ways to achive the instruction objectives such as the listening course at the level of university.

\section{METHOD}

The study was carried out at STKIP Tapanuli Selatan for three months (March to July 2017). It was located on Jalan Sutan Muhammad Arif Padangsidimpuan. The name of Dean is Drs. H. Muhammad Nau Ritonga, M.M. and the Head of English Education Program is Nurhafni Siregar, S.Pd., M.Hum. The informants of this research consist of a lecturer of listening comprehension and 63 English Department students of STKIP Tapanuli Selatan in second semester in 2016/2017 Academic Year. This study is a qualitative research and to collect the data, observation, interview, and questionnaire were applied. The data were analyzed by using data reduction, data display and drawing conclusion.

\section{FINDINGS}

The findings of this study cover the classroom practice in teaching listening comprehension, that classified into two major things, they are classroom activities that lecturer uses when teaching listening comprehension and the students responses to the lecturer's classroom activities.

\section{Classroom Activities that Lecturer Used when Teaching Listening Comprehension}

The lecturer in interview admitted that she has taught listening comprehension from 11 years and taught 63 students in
2 classes. In teaching listening, she starts from preparation, planning, listening, and reflection. When choosing activities to teach listening, she considers the indicators and objectives of the study. To help the students when they have difficulty understanding the listening activity, she gives clues to the students before listening. She assesses listening activity by giving test, multiple choices, and structural essay. According to her, teaching listening is exciting, moreover when you have found good materials and appropriate test. Students are encouraged to solve the problems if they are given enough clues.

In teaching listening comprehension, the lecturer uses text book with audio tapes and videos and usually teaches the listening section included the text book. She teaches listening skills by integrating with other skills, especially with speaking skill. According to her, the listening text prepared for second semester match with the students' level understanding. Then, in teaching listening comprehension, the lecturer usually follow the suggested procedures proposed for presenting the listening lesson because it is quiet suitable in her classes. In her opinion, teaching listening is very important for the students.

Based on the questionnaire given, the lecturer responses are suitable when the researcher has done the observation. She always introduce the listening text and activities before start to listen, and always set purposes for each listening activity. The other crucial activity is making the instruction clear to the students. With regard to this, the lecturer replied that she always made instructions clear. What was seen during the observation supported the lecturer responds. That is, the lecturer was seen doing this.

Regarding whether the lecturer taught some words used in the passage, the lecturer responded that she always do that before the students listen to the text. In item number 5 in lecturer's questionnaire, the lecturer said that she usually help her students to predict about the text. What was seen during the observation showed that the lecturer's answer is match. In order to bring effective listening in the classroom, the students should know the reason why they are listening. The lecturer responded that she usually makes her students understand the reason. However, the data gathered through observation depict that the lecturer does not implement this activity frequently.

Concerning to the item 7 in lecturer's questionnaire, the lecturer responded that she always tells the students to copy the questions, tables, etc before they start listening. Furthermore, the practice were seen during the observation that the lecturer asks the student to copy the questions they were going to work on. In the item 8 , the lecturer pointed out that she usually telling students to listen and match activities. However, in the data gathered through observation it was seen that the lecturer practice this activity.

Concerning item number 9 in lecturer's questionnaire, the lecturer responded that she usually engages her students in some listen and follow activities such as drawing picture, completing tabel, etc. But the data gathered during the observation contradicts with this. The lecturer was not seen handling these activities in all the observation sessions. 
Next, the lecturer said that she always encourage the students to listen and complete a form. Pertaining to the next questionnaire items, the lecturer replied that she sometimes tell the students to listen and respond physically in listening class. The data gathered through questionnaire and observation depict that the lecturer does not implement this activity frequently.

Regarding whether the lecturer make the students to listen and complete factual errors, the lecturer responded that she sometimes do this. The data found from the observations showed that the teacher was not seen using this activity. With regard to item number 13 , the lecturer responded that she always telling her students to discuss with their partners and compare and complete their notes. Then she always move from group to group to check whether students discuss in English when they are doing some activities. It is match with the observation result.

Pertaining to item number 15 , the lecturer responded that sometimes she engage the students in role play activities. However, what was found from the observation supports the lecturer's respond. She was not seen making her students play roles in all of the observations. In the next item of lecturer's questionnaire, the lecturer responded she usually let her students express their views and opinions based on the idea reflected in the listening text, and sometimes engage in extensive writing exercise.

It is natural that students want to get feedback for what they tried to perform in the classroom. This feedback, as much as possible, should be positive to ensure learners to experience success as often as possible. With regard to appropriate feedback, the responses from the lecturer and the findings from classroom observation reveal that lecturer always give appropriate feedback.

\section{Students Responses to the Lecturer's Classroom Activities}

The data of students responses to the lecturer's classroom activities was collected from questionnaire. The teaching of listening involves different practices at different stages. The practice at pre-, while-, and post-listening are analyzed as follows:
As indicated in the Table 1, the practice of lecturer in discussing the topic of listening text to connect it with what the students already know, 23 or $36,5 \%$ of students responded that their lecturer always discuss the topic, 19 or $30,1 \%$ usually, 10 or $16 \%$ sometimes, 8 or $13 \%$ rarely, and the rest 3 or $5 \%$ never.

Concerning item 2, 26 or $41,2 \%$ of students replied that their lecturer always asks them to preview questions that they have to answer while listening. While 19 or $30,1 \%$ replied usually, 10 or $6 \%$ sometimes, 5 or $8 \%$ rerely, and 3 or $5 \%$ never. Regarding item 3, most of students respondents 29 or $46 \%$ and 20 or $32 \%$ that the lecturer always and usually asks them to study new vocabularies. The other 14 students stated that their lecturer sometimes, rarely and never do that.

Item 4 deals with the lecturer ask students to discuss visual (graphs, tables or pictures) to provide context. Only 5 or $8 \%$ and 10 or $16 \%$ of students replied that their lecturer always and usually do that. While 29 or $46 \%$ of students said the lecture sometimes do that. The other students, 14 or $22,2 \%$ and 5 or $8 \%$ said rearely and never. Based on the students responds, it means that the lecture rarely or never ask them to discuss that. Item 5 is make prediction about what the students will hear. As many as 19 or $30 \%$ of students responded that their lecturer always practicing that. While 17 or $27 \%$ said usually, 12 or $19 \%$ sometimes, 7 or $11,1 \%$ rarely, and the rest 8 or $13 \%$ never.

According to item 6, it shows that most of students think that their lecturer always and usually asks them to read the listening text. 10 or $16 \%$ students think that the lecture sometimes do it, while 5 or $8 \%$ and 2 or $3,1 \%$ of them said that their lecturer rerely and never do it. From the results of students questionnaire above, it shows that in practicing pre-listening activities, lecturer have employed most of essential activity for best learning of the students while some of the item is not practiced.

According to Table 2, in item 10 most of students responded that the lecture always and usually asks them to read the listening text. While the rest, 10 or $16 \%$ of students stated sometimes, 5 or $8 \%$ rarely, and 2 or $3,1 \%$ never. Regarding to item 11 the lecturer asks the students to take notes, 5 or $8 \%$ and 3 or $5 \%$ of students stated that the lecturer always

Table 1. Students' Questionnaire in Pre-listening

\begin{tabular}{|c|c|c|c|c|c|c|}
\hline Before we listen, the lecturer asks us & $\begin{array}{l}\text { Never } \\
(\%)\end{array}$ & $\begin{array}{c}\text { Rarely } \\
(\%)\end{array}$ & $\begin{array}{c}\text { Some-times } \\
(\%)\end{array}$ & $\begin{array}{c}\text { Usually } \\
(\%)\end{array}$ & $\begin{array}{c}\text { Always } \\
(\%)\end{array}$ & $\begin{array}{c}\text { Total } \\
(\%)\end{array}$ \\
\hline $\begin{array}{l}\text { Discuss the topic of the listening text to connect it } \\
\text { with what we already know. }\end{array}$ & $\begin{array}{c}3 \\
(5)\end{array}$ & $\begin{array}{c}8 \\
(13)\end{array}$ & $\begin{array}{c}10 \\
(16)\end{array}$ & $\begin{array}{c}19 \\
(30.1)\end{array}$ & $\begin{array}{c}23 \\
(36.5)\end{array}$ & $\begin{array}{c}63 \\
(100)\end{array}$ \\
\hline Preview questions to be answered while listening & $\begin{array}{c}3 \\
(5)\end{array}$ & $\begin{array}{c}5 \\
(8)\end{array}$ & $\begin{array}{c}10 \\
(16)\end{array}$ & $\begin{array}{c}19 \\
(30.1)\end{array}$ & $\begin{array}{c}26 \\
(41.2)\end{array}$ & $\begin{array}{c}63 \\
(100)\end{array}$ \\
\hline Study new vocabulary & $\begin{array}{l}3 \\
(5)\end{array}$ & $\begin{array}{c}5 \\
(8)\end{array}$ & $\begin{array}{c}6 \\
(9.5)\end{array}$ & $\begin{array}{c}20 \\
(32)\end{array}$ & $\begin{array}{c}29 \\
(46)\end{array}$ & $\begin{array}{c}63 \\
(100)\end{array}$ \\
\hline $\begin{array}{l}\text { Discuss visual (graphs, tables or pictures) to provide } \\
\text { context. }\end{array}$ & $\begin{array}{c}5 \\
(8)\end{array}$ & $\begin{array}{c}14 \\
(22.2)\end{array}$ & $\begin{array}{l}29 \\
(46)\end{array}$ & $\begin{array}{c}10 \\
(16)\end{array}$ & $\begin{array}{c}5 \\
(8)\end{array}$ & $\begin{array}{c}63 \\
(100)\end{array}$ \\
\hline Make prediction about what we will hear. & $\begin{array}{c}8 \\
(13)\end{array}$ & $\begin{array}{c}7 \\
(11.1)\end{array}$ & $\begin{array}{c}12 \\
(19)\end{array}$ & $\begin{array}{l}17 \\
(27)\end{array}$ & $\begin{array}{c}19 \\
(30.1)\end{array}$ & $\begin{array}{c}63 \\
(100)\end{array}$ \\
\hline Read the listening text & $\begin{array}{c}2 \\
(3,1)\end{array}$ & $\begin{array}{c}5 \\
(8)\end{array}$ & $\begin{array}{c}10 \\
(16)\end{array}$ & $\begin{array}{c}20 \\
(32)\end{array}$ & $\begin{array}{c}25 \\
(40)\end{array}$ & $\begin{array}{c}63 \\
(100)\end{array}$ \\
\hline
\end{tabular}


and usually do it. While 10 or $16 \%$ of students stated sometimes, 26 or $41,2 \%$ rarely, and 19 or $30,1 \%$ never. It means that the lecturer rarely or never practice the stated item.

The next item, the lecturer asks the students to complete exercises, most of students replied always and usually. While the other students replied sometimes, rarely, and never. Item 13 deal with the lecturer asks the student to complete or sequence pictures. Only 5 or $8 \%$ and 8 or $13 \%$ of students responded that the lecturer always and usually practice that. Most of students respond that the lecturer sometimes, rarely and never practice that. Concerning to item 14, which deals with the lecturer asks the students to complete charts, tables, or forms, only 8 or $13 \%$ and 7 or $11,1 \%$ of students reported that their lecturer always and usually ask them to do it. While the rest 48 students stated their lecture sometimes, rarely and never practice it.

In item 15 , most of students, 20 or $32 \%$ and 14 or $22,2 \%$ responded that their teacher sometimes, rerely and never asks them to write what they have heard. Only 3 or 5\%, 12 or $19 \%$ of students responded always and usually. Item 16 of Table 2 is concerned with carry out actions that the students hear. Only 4 or $6,3 \%$ and 7 or $11,1 \%$ of students said that the lecturer practice this item in while-listening stage. Most of students replied that the lecture sometimes, rarely and never practice it. The last item in Table 2, verify of evaluate the students predictions. 23 or $36,5 \%$ and 19 or $30,1 \%$ of students responded the lecturer practice that stated item. 10 or $16 \%$ of students responded sometimes, and the rest said rarely and never. From the results of questionnaire above, we can see that the lecturer does not practice most of strategies in order to make students interest to listen the material.

According to Table 3, item 21 above most of students responded that the lecture always and usually asks them to read the listening text. While the rest, 10 or $16 \%$ of students stated sometimes, 5 or $8 \%$ rarely, and 2 or $3,1 \%$ never. Item 22 deals with the lecturer ask the students to write a summary of paragraph about the listening. Only 3 or $5 \%$ and 5 or $8 \%$ of students responded that the lecturer always and usually practice that. Most of students responded the students rarely or never practice that. Concerning to item 23 , only 3 or $5 \%$ and 5 or $8 \%$ of students replied their lecturer always and usually ask the to complete charts, tables or forms. Most of students, 19 or $30,1 \%$ and 26 or $41,2 \%$ responded the lecturer rarely and never do it.

In item 24, ask students to complete exercises, most of students said their lecturer always and usually practice that. Concerning to asks the students to repeat the text, 20 or $32 \%$ and 15 or $24 \%$ of students replied that the lecturer always and usually practice that stated item. And the rest, 11 or $17,4 \%$ students replied sometimes, 8 or $13 \%$ rarely, and 9 or $14,2 \%$ never. In item 26 , the lecturer asks students to make role-play the situation. Most of the students replied the lecturer rarely and never practice that. Only 3 or $5 \%$ and 5 of $8 \%$ of students stated the lecturer always and usually do that.

Concerning to asks the students to use the information for problem solving or other task-oriented activities, 3 or 5\% and 20 or $32 \%$ of students replied that the lecturer practice that. While 12 or $19 \%$ sometimes, 14 or $22,2 \%$ rarely and never. The next, item 28 in table 3, most of students responded that the lecturer always and usually ask them to discuss discrepancies in their predictions. And the last item, set goals for future listening activities, 22 or $35 \%$ and 15 or $24 \%$ of students responded the lecturer always and usually practice it, and the rest 18 or $28,5 \%$ sometimes, 9 or $14,2 \%$ rarely, and 9 or $14,2 \%$ never.

In teaching listening comprehension, most of students stated that their lecturer using audio visual about 15 minutes

Table 2. Students' questionnaire in While-listening

\begin{tabular}{|c|c|c|c|c|c|c|}
\hline While we listen, the lecturer asks us: & $\begin{array}{l}\text { Never } \\
\%\end{array}$ & $\begin{array}{c}\text { Rarely } \\
\%\end{array}$ & $\begin{array}{c}\text { Some-times } \\
\% \\
\end{array}$ & $\begin{array}{l}\text { Usually } \\
\%\end{array}$ & $\begin{array}{l}\text { Always } \\
\%\end{array}$ & $\begin{array}{c}\text { Total } \\
\%\end{array}$ \\
\hline Read the listening text & $\begin{array}{c}2 \\
(3.1)\end{array}$ & $\begin{array}{c}5 \\
(8)\end{array}$ & $\begin{array}{c}10 \\
(16)\end{array}$ & $\begin{array}{c}20 \\
(32)\end{array}$ & $\begin{array}{c}25 \\
(40)\end{array}$ & $\begin{array}{c}63 \\
(100)\end{array}$ \\
\hline Take notes & $\begin{array}{c}19 \\
(30.1)\end{array}$ & $\begin{array}{c}26 \\
(41.2)\end{array}$ & $\begin{array}{c}10 \\
(16)\end{array}$ & $\begin{array}{c}3 \\
(5)\end{array}$ & $\begin{array}{c}5 \\
(8)\end{array}$ & $\begin{array}{c}63 \\
(100)\end{array}$ \\
\hline $\begin{array}{l}\text { Complete exercises } \\
\text { (e.g., true/false, multiple choice, gap-fill) }\end{array}$ & $\begin{array}{c}3 \\
(5)\end{array}$ & $\begin{array}{c}8 \\
(13)\end{array}$ & $\begin{array}{c}10 \\
(16)\end{array}$ & $\begin{array}{c}23 \\
(36.5)\end{array}$ & $\begin{array}{c}19 \\
(30.1)\end{array}$ & $\begin{array}{c}63 \\
(100)\end{array}$ \\
\hline Complete or sequence pictures & $\begin{array}{l}25 \\
(40)\end{array}$ & $\begin{array}{l}15 \\
(24)\end{array}$ & $\begin{array}{c}10 \\
(16)\end{array}$ & $\begin{array}{c}8 \\
(13)\end{array}$ & $\begin{array}{c}5 \\
(8)\end{array}$ & $\begin{array}{c}63 \\
(100)\end{array}$ \\
\hline Complete charts, tables, or forms & $\begin{array}{c}19 \\
(30.1)\end{array}$ & $\begin{array}{l}17 \\
(27)\end{array}$ & $\begin{array}{c}12 \\
(19)\end{array}$ & $\begin{array}{c}7 \\
(11.1)\end{array}$ & $\begin{array}{c}8 \\
(13)\end{array}$ & $\begin{array}{c}63 \\
(100)\end{array}$ \\
\hline Write what we hear (dictation) & $\begin{array}{c}14 \\
(22.2)\end{array}$ & $\begin{array}{c}14 \\
(22.2)\end{array}$ & $\begin{array}{c}20 \\
(32)\end{array}$ & $\begin{array}{c}12 \\
(19)\end{array}$ & $\begin{array}{c}3 \\
(5)\end{array}$ & $\begin{array}{c}63 \\
(100)\end{array}$ \\
\hline Carry out actions that we hear & $\begin{array}{c}12 \\
(40)\end{array}$ & $\begin{array}{c}12 \\
(19)\end{array}$ & $\begin{array}{c}15 \\
(24)\end{array}$ & $\begin{array}{c}7 \\
(11.1)\end{array}$ & $\begin{array}{c}4 \\
(6.3)\end{array}$ & $\begin{array}{c}63 \\
(100)\end{array}$ \\
\hline Verify or evaluate their predictions & $\begin{array}{c}3 \\
(5)\end{array}$ & $\begin{array}{c}8 \\
(13)\end{array}$ & $\begin{array}{c}10 \\
(16)\end{array}$ & $\begin{array}{c}19 \\
(30.1)\end{array}$ & $\begin{array}{c}23 \\
(36.5)\end{array}$ & $\begin{array}{c}63 \\
(100)\end{array}$ \\
\hline \multicolumn{7}{|l|}{ Other } \\
\hline \multicolumn{7}{|l|}{ Other } \\
\hline Other & & & & & & \\
\hline
\end{tabular}


Table 3. Students' Questionnaire in Post-listening

\begin{tabular}{|c|c|c|c|c|c|c|}
\hline After we listen, the lecturer asks us & $\begin{array}{c}\text { Never } \\
\%\end{array}$ & $\begin{array}{c}\text { Rarely } \\
\%\end{array}$ & $\begin{array}{c}\text { Some-times } \\
\%\end{array}$ & $\begin{array}{c}\text { Usually } \\
\%\end{array}$ & $\begin{array}{c}\text { Always } \\
\%\end{array}$ & $\begin{array}{c}\text { Total } \\
\%\end{array}$ \\
\hline Read the listening text. & $\begin{array}{c}2 \\
(3.1)\end{array}$ & $\begin{array}{c}5 \\
(8)\end{array}$ & $\begin{array}{c}10 \\
(16)\end{array}$ & $\begin{array}{c}20 \\
(32)\end{array}$ & $\begin{array}{c}25 \\
(40)\end{array}$ & $\begin{array}{c}63 \\
(100)\end{array}$ \\
\hline Write a summary of paragraph about the listening. & $\begin{array}{c}26 \\
(41.2)\end{array}$ & $\begin{array}{c}19 \\
(30.1)\end{array}$ & $\begin{array}{c}10 \\
(16)\end{array}$ & $\begin{array}{c}5 \\
(8)\end{array}$ & $\begin{array}{c}3 \\
(5)\end{array}$ & $\begin{array}{c}63 \\
(100)\end{array}$ \\
\hline Complete charts, tables, or forms & $\begin{array}{c}26 \\
(41.2)\end{array}$ & $\begin{array}{c}19 \\
(30.1)\end{array}$ & $\begin{array}{c}10 \\
(16)\end{array}$ & $\begin{array}{c}5 \\
(8)\end{array}$ & $\begin{array}{c}3 \\
(5)\end{array}$ & $\begin{array}{c}63 \\
(100)\end{array}$ \\
\hline Complete exercises (e.g., true/false, multiple choice, gap-fill) & $\begin{array}{c}8 \\
(13)\end{array}$ & $\begin{array}{c}7 \\
(11.1)\end{array}$ & $\begin{array}{l}12 \\
(19)\end{array}$ & $\begin{array}{c}17 \\
(27)\end{array}$ & $\begin{array}{c}19 \\
(30.1)\end{array}$ & $\begin{array}{c}63 \\
(100)\end{array}$ \\
\hline Repeat the text & $\begin{array}{c}9 \\
(14.2)\end{array}$ & $\begin{array}{c}8 \\
(13)\end{array}$ & $\begin{array}{c}11 \\
(17.4)\end{array}$ & $\begin{array}{c}15 \\
(24)\end{array}$ & $\begin{array}{c}20 \\
(32)\end{array}$ & $\begin{array}{c}63 \\
(100)\end{array}$ \\
\hline Role-play the situation & $\begin{array}{c}29 \\
(46)\end{array}$ & $\begin{array}{c}20 \\
(32)\end{array}$ & $\begin{array}{c}6 \\
(9.5)\end{array}$ & $\begin{array}{c}5 \\
(8)\end{array}$ & $\begin{array}{c}3 \\
(5)\end{array}$ & $\begin{array}{c}63 \\
(100)\end{array}$ \\
\hline $\begin{array}{l}\text { Use the information for problem solving or other } \\
\text { task-oriented activities }\end{array}$ & $\begin{array}{c}14 \\
(22.2)\end{array}$ & $\begin{array}{c}14 \\
(22.2)\end{array}$ & $\begin{array}{c}12 \\
(19)\end{array}$ & $\begin{array}{c}20 \\
(32)\end{array}$ & $\begin{array}{c}3 \\
(5)\end{array}$ & $\begin{array}{c}63 \\
(100)\end{array}$ \\
\hline Discuss discrepancies in our predictions & $\begin{array}{c}6 \\
(9.5)\end{array}$ & $\begin{array}{c}7 \\
(11.1)\end{array}$ & $\begin{array}{c}9 \\
(14.2)\end{array}$ & $\begin{array}{c}18 \\
(28.5)\end{array}$ & $\begin{array}{c}23 \\
(36.5)\end{array}$ & $\begin{array}{c}63 \\
(100)\end{array}$ \\
\hline Set goals for future listening activities & $\begin{array}{c}9 \\
(14.2)\end{array}$ & $\begin{array}{c}9 \\
(14.2)\end{array}$ & $\begin{array}{c}18 \\
(28.5)\end{array}$ & $\begin{array}{l}15 \\
(24)\end{array}$ & $\begin{array}{c}22 \\
(35)\end{array}$ & $\begin{array}{c}63 \\
(100)\end{array}$ \\
\hline \multicolumn{7}{|l|}{ Other: } \\
\hline Other: & & & & & & \\
\hline
\end{tabular}

and reply it more than once. The lecturer usually using dialog, song, or sometimes read the text. To assess their listening, the lecturer makes a test to them. From the data of students' questionnaire above we can concluded that most of items in pre-, while-, and post-listening still haven't done by the lecturer. The lecturer still have to find a creative strategies that make students interest in listening.

\section{CONCLUSIONS}

The findings of the study give some conclusions, they are: (1) practicing the pre-listening, the dominant activities did by the lecturer are: studying new vocabulary, previewing questions to be answered while listening, reading the listening text, discussing the topic of the listening text to connect it with what we already know, and making prediction about what will be heard, while the less activity is discussing visual (graphs, tables or pictures) to provide context, (2) practicing the while-listening, the dominant activities did by the lecturer are read the listening text, verify or evaluate their predictions, and complete exercises (e.g. true/false, multiple choice, gap-fill). Whle the less activities are writing what we hear (dictation), carrying out actions that we hear, taking notes, completing or sequence pictures, and completing charts, tables, or forms, and (3) practicing the post listening, the dominant activities did by the lecturer are: Read the listening text., discussing discrepancies, setting goals for future listening activities, setting goals for future listening activities, completing exercises (e.g. true/false, multiple choice, gap-fill), while the less activities are: writing a summary of paragraph about the listening., completing charts, tables, or forms, making role-play the situation, using the information for problem solving or other task-oriented activities.

Based on the above conclusions, it is suggested that in order to be more effective in teaching listening comprehension at English Education Program of STKIP Tapanuli Selatan, the lecturer should pay more attention to the implementation of: discussing visual (graphs, tables or pictures) to provide context in pre-listening, writing what we hear (dictation), carrying out actions that we hear, taking notes, completing or sequence pictures, and completing charts, tables, or forms in while listening, and writing a summary of paragraph about the listening., completing charts, tables, or forms, making role-play the situation, using the information for problem solving or other task-oriented activities in post listening.

\section{REFERENCES}

Alqahtani, Mofareh. 2015. The Importance of Vocabulary in Language Learning and How to be Taugh. International Journal of Teaching and Education. Vol. III, No. 3.

Al-Zughoul, Basem. 2014. Implicit Referential Meaning with Reference to English Arabic Translation. English Language Teaching. Tahun 2014; 168.

Bazo, Placido, et. al. 2007. Evaluating A Foreign Language in Primary Education. Glosas Didacticas: Revista Electronica Internacional.University of La Laguna. Tahun 2007; 66.

Beech, Linda Ward. 2005. Reading Passages That Build Comprehension: Main Idea \& Details. New York: Scholastic Inc.

Chomsin S. Widodo dan Jasmadi. 2008. Panduan Menyusun Bahan Ajar Berbasis Kompetensi. Jakarta: Gramedia. 
Debela, Emnet. 2015. An Investigation of Teachers' Perception and their Classroom practices in Teaching Listening Com prehension: Unpublished thesis: Ilu Aba Bor Zone: Jimma University. Available at https://opendocs.ids.ac.uk/opendocs/handle/123456789/9715. Accessed on $3^{\text {rd }}$ March 2017.

Liu \& Shi, 2008. Teaching and Learning in the Language Classroom. New York: Oxford University Press.

Markham, Lois. 2006. Focus on Main Idea and Details. USA: Curriculum Associates, Inc.

Nation, I.S.P \& Newton J., 2009. Teaching ESL/EFL Listening and Speaking. New York: Routledge.

Neuman, S. B., \& Dwyer, J. 2009. Missing in action: Vocabulary instruction in pre- $k$. The Reading Teacher.

Nuryadi, Wahyu Dwi Savitri. 2013. Teaching Listening Comprehension through Voice of America (VOA) Special English Broadcast. Pontianak: Tanjungpura University.
Richard, C. Jack. 2008. Teaching Listening and Speaking. New York: Cambridge University

Rost, M. (2001).Listening. In R. Carter \& D. Nunan (Eds), The Cambridge Guide to Teaching EnglishTo Speakers of Other languages (PP. 7 - 13). Cambridge: Cambridge University press.

Sanjaya, Wina. 2009. Strategi Pembelajaran Berorientasi Standar Proses Pendidikan. Jakarta: Kencana Predana Media Group.

Sofyan, Amri. 2013. Pengembangan dan Model Pembelajaran dalam Kurikulum 2013. Jakarta: Prestasi Pustakarya.

Suwarni, Sri, et al., 2014. EnglishTeaching Material Development as an Alternative Source in Teaching English at Junior High Schools. International Journal of Research Studies in Language Learning Universitas Sebelas Maret. Vol 3 Tahun 2014; 98. 